\title{
Serbest Ticaret Anlaşmalarının Türkiye'nin Dış Ticaretine Etkileri: Açıklanmış Karşılaştırmalı Üstünlükler Endeksi Uygulaması
}

\author{
Cemalettin KALAYCI ${ }^{1}$
}

ÖZ: Avrupa Birliği başta olmak üzere birçok ülke dış ticaret hacimlerini artırmak ve sosyo ekonomik yarar sağlamak amacıyla diğer ülkelerle aralarındaki ticaret engellerini kaldırarak serbest ticaret anlaşmaları imzalamaktadır. Hem gümrük birliğinin gereği olarak, hem de diş ticarette dezavantajlı duruma düşmemek için Türkiye'de Avrupa Birliği'nin anlaşma yaptığ ülkelerle serbest ticaret anlaşmaları yapmaktadır. Türkiye yaklaşık olarak ihracatının \% 12 'sini, ithalatının ise \% 9'unu serbest ticaret anlaşması yapılan ülkelerle gerçekleştirmektedir. Çalışmada 2012-2016 dönemi için STA ülkeleriyle yapılan dış ticarette Türkiye'nin karşılaştırmal üstünlükleri analiz edilmiştir. Elde edilen bulgulara göre; "Türkiye'nin canlı hayvanlar ve glda maddeleri”, "içkiler ve tütün” ile "çeşitli mamul eşya" mal guruplarında karşılaştırmalı üstünlüğe; "akaryakıt hariç yenilmeyen hammaddeler", "hayvansal, bitkisel katı ve sıvı yağlar, mumlar" ve "başka yerde belirtilmeyen kimya sanayi ve buna bağll sanayi ürünleri" mal guruplarında ise karşılaş̧tırmalı dezavantaja sahip olduğu görülmektedir.

Anahtar Kelimeler: Serbest Ticaret Anlaşması, Açıklanmış Karşılaştırmalı Üstünlükler Endeksi, Dış Ticaret

Jel Kodu: F10, F12, F13, F15

\section{The Effects of Free Trade Agreements on Turkey's Foreign Trade: The Application of Revealed Comparative Advantage Index}

\begin{abstract}
In particular to European Union, many countries sign free trade agreements with the other countries by eliminating the trade barriers to enhance foreign trade volume and to gain socio-economic benefits. Turkey has been signing free trade agreements with the countries that European Union signed before, both for its being a requirement for customs union and not to face with a disadvantageous position in foreign trade. Turkey carries out approximately $12 \%$ of its export and $9 \%$ of its import with the countries that she signed free trade agreement. In this study, Turkey's comparative advantages in terms of the trade made with free trade agreement countries for 2012-2016 period are analyzed. According to the data obtained, it is clearly seen that while Turkey has comparative advantage at food and live animals, beverages and tobacco, and at group of some miscellaneous manufactured articles, it has comparative disadvantage in terms of crude materials except for fuel, fats and waxes, candles and chemicals and related products, n.e.s.
\end{abstract}

Keywords: Free Trade Agreement, Revealed Comparative Advantage Index, Foreign Trade Jel Codes: F10, F12, F13, F15

Geliş Tarihi / Received: 08/07/2017

Kabul Tarihi / Accepted: 22/09/2017

${ }^{1}$ Doç. Dr., Karadeniz Teknik Üniversitesi, İİBF, Çalışma Ekonomisi ve Endüstri İlişkileri Bölümü, ckalayci@ktu.edu.tr, orcid.org/0000-0002-7625-8767 


\section{Giriș}

Gümrük Tarifeleri ve Ticaret Genel Anlaşması (GATT) ile başlayıp Dünya Ticaret Örgütü (WTO) ile devam eden, dünya ticaretinin küresel düzeyde serbestleştirilmesi çabalarının yanında, bir çok ülke kendi aralarındaki ticaret hacmini artırmak başta olmak üzere bazı sosyo ekonomik yararlar elde etmek amaciyla, çeşitli ekonomik entegrasyonlar kurmakta veya serbest ticaret anlaşmaları (STA) imzalamaktadırlar. STA yapan ülkeler dışarıya karşı eski koruma oranlarını sürdürürken kendi aralarında ticareti serbestleştirmektedirler. Böylece serbest ticaret sayesinde ihtiyaç duydukları ürünleri birbirlerinden daha ucuza temin eden ülkeler arasında zamanla ticaret hacmi artmakta ve ekonomik büyüme sağlanmaktadır.

1980 öncesi dişa kapalı ithal ikameci politikalar uygulayan Türkiye 1980 sonrası ihracatı teșvike dayalı dıșa açık politikalar uygulamaya başlamıștır. Türkiye bu kapsamda bir yandan 1963 yılında yapılan Ankara Anlaşması ile başlayan Avrupa Birliği $(\mathrm{AB})$ 'ne üyelik sürecine hız verirken, bir yandan da bu sürecin gereği olarak bazı ülkelerle STA imzalamıştır. Daha sonra iki taraf arasında gümrük birliğin başlatan 1/95 sayılı Ortaklık Konseyi Kararı gereğince Türkiye AB'nin üçüncü ülkelere karşı uyguladığı tercihli rejimleri üstlenmek zorunda kalmıştır. Gerek bu zorunluluk gerekse ikili ticarette dezavantajlı duruma düşmemek için Türkiye AB'nin serbest ticaret anlaşması yaptığı ülkelerle STA imzalamaktadır.

Çalışmanın amacı gümrük birliği kapsamında yapılan STA'ların Türkiye'ye ticari etkilerini ortaya koyabilmek için STA imzalanan ülkeler ile olan ticarette Türkiye'nin karşılaştırmalı üstünlüklerini analiz etmektir.

Çalışmanın ikinci kısmında genel olarak serbest ticaret anlaşmaları, üçüncü kısımda Türkiye'nin imzaladığı serbest ticaret anlaşmalarının tarihsel gelişim süreci üzerinde durulmuştur. Dördüncü kısmında Türkiye'nin STA ülkeleriyle ticaretinin boyutu irdelenmiş, beşinci kısmında STA ülkeleri ile ticarette Türkiye'nin karşılaştırmalı üstünlükleri analiz edilmiştir. Çalışmanın son kısmında ise elde edilen bulguların ve çalışmanın genel bir değerlendirilmesi yapılmıştır.

\section{Serbest Ticaret Anlaşmaları}

Serbest ticaret anlaşması, iki ülke veya ülke grubu arasında bazı malların veya hizmetlerin ticaretinde uygulanan gümrük tarifelerini, kotaları ve tercihli uygulamaları ortadan kaldırmak için yapılan bir ticaret anlaşmasıdır. Genellikle bu anlaşmalar, gümrük sınırlarında ihracat ve ithalata uygulanan vergiler, standartlar ve prosedürler gibi ticareti kısitlayıcı önlemleri azaltarak veya kaldırarak, birbirlerinin piyasalarına giriş kolaylığı sağlamayı amaçlamaktadırlar. STA'lar mal veya hizmet ticaretini kapsayabileceği gibi aynı zamanda fikri mülkiyet hakları, yatırımlar, devlet ihaleleri ve rekabet politikaları gibi alanları da kapsayabilmektedir. Serbest ticaret anlaşmaları ile ticaret ve yatırımların önündeki 
engeller kaldırılarak işbölümü, uzmanlaşma ve en önemlisi karşılaştırmalı üstünlükler yoluyla ticaret hacmini artırmak amaçlanmaktadır (IMC, 2017: 1)

Kaynaklarını daha etkin kullanmak isteyen ülkeler, üye ülke üreticilerine daha geniş pazar olanakları sunmak için ticari işbirliği yoluna gitmektedirler. STA, iç pazarda korumacılığı azaltarak, diğer üye ülke pazarlarındaki firsatlardan yararlanma olanağı sağlamaktadır. Kendi aralarında işbirliği kuran ülkeler, daha büyük pazar ve endüstriler için ölçek ekonomileri oluşturacak üstünlük elde edebilirler. Ticaret engellerinin azaltılmasıyla rekabet artmakta ve sonuç olarak ekonomiye dinamizm kazandırılmaktadır. Ülke içerisindeki tüketim fazlası ve üretim olanağı blok ülkelerince desteklenerek endüstri teşvik edilmektedir. Bir grup ülke, kendi aralarında böyle bir bütünleşmeye gitme kararındaysalar, diğer GATT ülkelerine yaygınlaştırmaksızın aralarındaki ticareti serbestleştirebilmektedirler. Bu ayırımcı politikanın uygulanması GATT'ın 24.ncü maddesinde bazı şartlara bağlanmıştır. (Koçtürk ve Kocaefe, 2014: 67).

WTO kurallarına uygun olmak kaydıyla, serbest ticaret anlaşması imzalayan ülkeler anlaşmanın içeriğini istedikleri gibi düzenleyebilmektedirler. STA imzalayabilmek için taraf ülkelerin GATT kapsamında yerine getirmeleri gereken şartlar (Goode, 2005: 24-25);

- İki veya daha fazla gümrük bölgesinden meydana gelen bir serbest ticaret alanının oluşturulması,

- Malların taraf ülke menşeli olup olmadıklarına karar verebilmek için ortak menşe kurallarının belirlenmesi,

- Menşei STA'ya taraf olan ülkelere ait olan malların ticaretinde uygulanan bütün gümrük vergisi ve ticaret kısıtlamalarının kaldırılması,

- Üçüncü ülkelere karşı uygulanan ticaret engellerinin anlaşma sonrası artırılmamas1,

- STA'nın yürürlüğe koyulması kararına ilişkin WTO’ya hemen bilgi verilmesi,

şeklinde sıralanabilir.

\section{Türkiye'nin İmzaladığı Serbest Ticaret Anlaşmalarının Tarihsel Süreci}

WTO düzenlemelerinin günümüzün gereksinimlerini yeterince karşılayamaması ve çok taraflı ticaret düzeninin yeni pazar açılımları konusunda yetersiz kalması, ülkeleri ikili ve bölgesel ticaret anlaşmaları yapmaya yöneltmiştir. Serbest ticaret anlaşmaları son dönemde gerek gelişmiş ülkeler arasında, gerekse kuzey-güney ve güney-güney ticari ve ekonomik ilişkilerinde yaygınlaşmıştır. Ülkeler arasındaki STA ağının genişlemesi ile birçok ülke mal tedarikini STA ortaklarından temin ederken, STA ağlarının dışarısında kalan ülkeler tercihli ticaretin sağladığı imkânlardan mahrum kalmıştır. Domino etkisi yaratan bu durum, tüm ülkelerin 
artan bir şekilde STA ağları oluşturmalarını beraberinde getirmiştir (Ekonomi Bakanlığı, 2017a: 1).

Bu gelişmeler doğrultusunda Türkiye'de 1959 y1lında ilk üyelik başvuru ile başlattığı AB sürecini hızlandırmış ve Türkiye-AB Ortaklık Konseyinin 6 Mart 1995 tarihinde aldığı 1/95 sayılı kararla, Türkiye ile AB arasında gümrük birliği kurulmuştur.

Türkiye-AB arasında gümrük birliği 1 Ocak 1996 tarihinde yürürlüğe girmiş ve sanayi ürünlerinde karşılıklı gümrük tarife ve kotaları sonlandırılmıştır. Ayrıca, işlenmiş tarım ürünlerindeki sanayi payı da karşılıklı olarak gümrük vergisinden muaf tutulmuştur. Bu yeni uygulamalar ile beraber Türkiye üçüncü ülkelere karş1 sanayi ürünlerinde AB'nin ortak gümrük tarifesini uygulamaya başlamıştır. Gümrük birliğini kuran 1/95 sayılı Ortaklık Konseyi Kararı'nın 16. maddesinde topluluğun tercihli ticaret rejiminin 5 yıllık bir süre içinde Türkiye tarafindan üstlenilmesi karara bağlanmıştır. Bu kararla gümrük birliğinin de bir gereği olarak Türkiye az gelişmiş ülkelere Topluluğun sağlamış olduğu genelleştirilmiş tercihler sistemini ve Topluluğun diğer ülkelerle olan tercihli ticaret rejimini üstlenmekle yükümlü kılınmıştır. Söz konusu yükümlülük kapsamında Türkiye çok sayıda Orta ve Doğu Avrupa ülkesi ve Kuzey Afrika ülkeleri başta olmak üzere bir çok ülke ile serbest ticaret anlaşmaları imzalamıştır (Erdem, 2015: 27).

Bu çerçevede STA'lar, komşu ve çevre ülkelerle diş ticaretimizin geliştirilmesi; ihracatçılarımızın dış pazarlarda, başta $\mathrm{AB}$ ülkelerinin müteşebbisleri olmak üzere rakipleri ile eşit şartlarda rekabet edebilmesinin temini; karşılıklı yatırımların ve müşterek teşebbüslerle ülkemizin uluslararası rekabet gücünün artırılması bakımından önem taşımaktadır. $\mathrm{Bu}$ kapsamda, Türkiye'nin AB tarafından imzalanmış STA'ların içeriğini aynen kabul etme yükümlülüğü bulunmamakta olup, gerçekleştirilen müzakerelerde sanayi ve ticaret politikası önceliklerimiz ile ülkemizin hassasiyetleri göz önüne alınmaktadır. Türkiye bugüne kadar, 34 adet STA imzalanmış olup, Merkezi ve Doğu Avrupa ülkeleriyle imzalanmış olan 11 adet STA, bu ülkelerin AB üyelikleri nedeniyle feshedilmiştir. Geriye kalan 19 adet STA ise (EFTA [İsviçre, Norveç, İzlanda ve Lihtenştayn], İsrail, Makedonya, Bosna Hersek, Filistin, Tunus, Fas, Suriye, Misır, Arnavutluk, Gürcistan, Karadağ, Sırbistan, Şili, Ürdün, Morityus, Güney Kore, Malezya ve Moldova) halen yürürlüktedir (Ekonomi Bakanlığ1, 2017b: 1). Ancak Suriye ile imzalanan STA 6 Aralık 2011 tarihli Bakanlar Kurulu Kararı ile askıya alınmıştır.

AB ile STA imzalayan ve henüz Türkiye ile bir STA imzalamamış olan ülkelerin $\mathrm{AB}$ içinde serbest dolaşıma soktukları mallarını herhangi bir AB ülkesi üzerinden Türkiye pazarına gümrüksüz olarak sokma olanağına sahip olmaktadırlar. Türkiye ise, aynı şartlara ancak bu üçüncü ülke ile bir STA imzalaması durumunda sahip olacağından, bu ülkelerin Türkiye ile STA imzalama konusunda çok da istekli davranmadıkları görülmektedir. Türkiye'nin AB'nin STA yaptığı üçüncü ülkelerle kendisinin de sorunsuz bir şekilde anlaşma yapabilmesi için AB Komisyonunun yapılan anlaşmalara Türkiye ile ilgili bir madde koyması gerekmektedir. Aksi 
takdirde bu ülkeler, bir yaptırım olmadığı için Türkiye ile anlaşma imzalamaya yanaşmamaktadırlar. $\mathrm{AB}$, yaptığı STA anlaşmalarına $\mathrm{AB}$ gümrük alanının bir parçası olan Türkiye ile ilgili bağlayıcı nitelikte bir madde koymayı istemediğinden bu sorun çözülememektedir. Ayrıca Türkiye maddesi dikkate alınmak istense bile, bu maddenin uygulanması anlaşma imzalandığı tarihte söz konusu olacağı için, Türkiye'nin ilgili ülke ile müzakerelere çok geç başlamasına neden olabilecektir (Eren, 2013: 43)

Yukarıda belirtildiği gibi, AB ile STA imzalayan ülkelere ait serbest ticaret kapsamındaki mallar Türkiye'ye gümrüksüz olarak girebilirken, Türkiye'ye ait malların söz konusu ülkelere gümrüksüz olarak gidebilmesi Türkiye'nin o ülkelerle serbest ticaret anlaşması yapmasına bağlıdır. Bu kapsamda $A B$ ile anlaştığında mallarını Türkiye'ye de gümrüksüz gönderebileceğinin farkında olan Meksika, Güney Afrika, Cezayir gibi ülkeler Türkiye ile STA imzalamaya yanaşmamaktadırlar. Böylece AB ile STA imzalayıp Türkiye ile STA imzalamak istemeyen ülkelere karşı Türkiye ikili ticarette dezavantajlı duruma düşmektedir. AB'nin ABD gibi belirli bir ekonomik büyüklüğe sahip olan ülkelerle STA imzalamak için girişimlerde bulunmuş olması, Türkiye'nin gelecekte bu kapsamda ciddi ticari zararlara uğrama ihtimalini artırmaktadır.

$A B$ ve $A B D$ ekonomileri birlikte dünya GSYİH'sının yaklaşık yarısını, küresel ticaretin ise neredeyse üçte birine temsil etmektedir. Her ne kadar iki ekonomik alan bir birine son derece entegre olmasına rağmen, serbest ticaret anlaşması çerçevesinde daha fazla ekonomik işbirliği için halen önemli bir potansiyel bulunmaktadır (Kinnman ve Hagberg, 2012: 5).

$A B$ ve $A B D$ arasında çok kapsamlı ticaret ve yatırım ortaklığı kurulması amacıyla 13 Şubat 2013 tarihinde başlayan Transatlantik Ticaret ve Yatırım Ortaklığ 1 (TTIP) oluşturma süreci halen devam etmektedir (Sandalcılar ve Palyoş, 2017: 38). TTIP, $A B D$ ürünlerine $A B$ üzerinden Türk pazarına serbest bir giriş imkanı sağlarken, Türkiye'nin ABD'ye ihracatı gümrük vergisi gibi kısıtlamalara tabi olmaya devam edecektir. Bu durum, bir yandan ABD ile mevcut ticaret dengesini olumsuz etkileyecek, diğer yandan ise Türk ürünlerinin $\mathrm{AB}$ ürünleri karşısında ABD pazarındaki rekabet imkanını azaltacaktır. Daha önemlisi TTIP, Türkiye'nin diş ticaretinde çok önemli bir paya sahip olan bu iki ekonomiyle, mal ve hizmet ticareti ile yatırımlar alanında yeni belirlenecek düzenlemeler ve normlara göre hareket etmesini gerektirecektir. Bu şartlar altında, Türkiye'nin ABD ile bir serbest ticaret anlaşması yapması giderek ve artan şekilde önem kazanmaktadır (Akman, 2013: 2).

\section{Türkiye'nin STA Ülkeleriyle Ticaretinin Boyutu}

Türkiye ile $\mathrm{AB}$ arasında gümrük birliği kurulmasını sağlayan 1/95 sayılı Ortaklık Konseyi Kararının 16/1.maddesinde "Türkiye, ticaret politikasını Topluluğun Ticaret Politikasına uyumlu hale getirmek amacıyla bu Kararın yürürlüğe girmesinden itibaren beş yll içinde Topluluğun tercihli gümrük rejimine aşamalı 
olarak uyum sağlar. Вu uyum, hem otonom rejimleri hem de üçüncü ülkelerle tercihli anlaşmaları kapsar. Bu amaçla, Türkiye gerekli önlemleri alır ve ilgili ülkelerle karşılıkl yarar temeline dayanan anlaşmaları müzakere eder. Ortaklık Konseyi, kaydedilen gelişmeleri düzenli aralıklarla inceler" denilmektedir (AB Bakanlığı, 2017: 7). Türkiye bu kapsamda gerek ikili ticarette dezavantajlı duruma düşmemek gerekse serbest ticaret yoluyla ticaret hacmini artırmak amaçlarıyla AB'nin serbest ticaret anlaşması yaptığı birçok ülkeyle karşılıklı yarar esasına dayalı olarak STA imzalamaya devam etmektedir.

Türkiye'nin STA ülkelerine ihracatı yıllar itibariyle Tablo 1'de verilmiştir. 20122016 dönemi incelendiğinde Türkiye'nin STA ülkelerine ihracatının 2016 yılı hariç genelde artış trendinde olduğu görülmektedir. 2012 yılında yaklaşık olarak 15,3 milyar dolar olan toplam ihracat 2015 yılında 20,5 milyar dolara çıksa da, 2016 yılında azalarak 17,6 milyar dolar olarak gerçekleşmiştir. STA ülkelerine yapılan ihracatın Türkiye'nin toplam ihracatı içindeki payı yaklaşık olarak yüzde 12 civarındadır. Türkiye'nin STA ülkelerine ihracatı içinde en fazla paya sahip olan ülkeler ise EFTA ülkeleri (EFTA ülkelerine yapılan ihracatın yaklaşık yüzde 80'den fazlası İsviçre ile gerçekleştirilmektedir), Mısır ve İsrail'dir.

Tablo 1: Türkiye'nin STA Ülkelerine İhracatı (Bin \$)

\begin{tabular}{|c|c|c|c|c|c|c|}
\hline & 2012 & 2013 & 2014 & 2015 & 2016 & $\begin{array}{c}\text { Ortalama } \\
\text { İhracat }\end{array}$ \\
\hline EFTA & 2.601 .134 & 1.661 .908 & 3.795 .180 & 6.202 .203 & 3.266 .797 & 3.505 .444 \\
\hline Arnavutluk & 255.950 & 266.544 & 318.541 & 287.374 & 304.612 & 286.604 \\
\hline Moldova & 224.464 & 275.971 & 286.741 & 201.607 & 262.383 & 250.233 \\
\hline Gürcistan & 1.253 .309 & 1.245 .917 & 1.443 .790 & 1.108 .740 & 1.176 .791 & 1.245 .709 \\
\hline Bosna Hersek & 251.523 & 274.086 & 322.022 & 292.570 & 308.962 & 289.833 \\
\hline Makedonya & 274.497 & 293.976 & 347.965 & 324.613 & 378.038 & 323.818 \\
\hline Karadağ & 29.131 & 29.140 & 35.040 & 38.297 & 51.807 & 36.683 \\
\hline Surbistan & 380.869 & 440.650 & 506.419 & 492.472 & 581.776 & 480.437 \\
\hline Fas & 1.014 .906 & 1.192 .900 & 1.406 .566 & 1.337 .555 & 1.469 .254 & 1.284 .236 \\
\hline Tunus & 796.738 & 892.157 & 915.041 & 819.061 & 910.444 & 866.688 \\
\hline Misır & 3.679 .195 & 3.200 .362 & 3.297 .538 & 3.124 .876 & 2.733 .426 & 3.207 .079 \\
\hline Morityus & 35.550 & 40.347 & 37.802 & 34.295 & 35.521 & 36.703 \\
\hline Şili & 174.852 & 219.338 & 198.579 & 187.881 & 217.164 & 199.563 \\
\hline Suriye & 497.960 & 1.024 .473 & 1.800 .962 & 1.522 .032 & 1.322 .151 & 1.233 .516 \\
\hline İsrail & 2.329 .531 & 2.649 .663 & 2.950 .902 & 2.698 .139 & 2.955 .677 & 2.716 .782 \\
\hline Filistin & 62.696 & 75.507 & 90.945 & 82.224 & 94.372 & 81.149 \\
\hline Ürdün & 770.982 & 744.193 & 907.021 & 834.756 & 710.803 & 793.551 \\
\hline Malezya & 165.474 & 272.073 & 315.024 & 357.083 & 321.564 & 286.244 \\
\hline Güney Kore & 527.993 & 460.050 & 470.464 & 568.635 & 518.829 & 509.194 \\
\hline $\begin{array}{l}\text { STA } \\
\text { (Toplam) }\end{array}$ & 15.326 .754 & 15.259 .255 & 19.446.542 & 20.514.413 & 17.620.371 & 17.633 .467 \\
\hline Pay $(\%)$ & 0,10 & $\mathbf{0 , 1 0}$ & 0,12 & 0,14 & 0,12 & 0,12 \\
\hline $\begin{array}{l}\text { Türkiye } \\
\text { (Toplam) }\end{array}$ & 152.461.737 & 151.802.637 & 157.610 .158 & 143.838 .871 & 142.544 .457 & 149.651.572 \\
\hline
\end{tabular}

Kaynak: https://biruni.tuik.gov.tr/disticaretapp/menu.zul 
Türkiye'nin STA ülkelerinden ithalatı yıllar itibariyle Tablo 2'de verilmiştir. Tablodan da görüleceği üzere STA ülkelerine yapılan toplam ithalat 2012-2016 döneminde dalgalanma göstermektedir. Şöyle ki, 2012 yılında yaklaşık olarak 17,3 milyar dolar olan ithalat, 2013 y1lında artarak 24,5 milyar dolar olmuştur. Daha sonraki yıllarda azalan ithalat 2016 yılında yaklaşık olarak 17 milyar dolar olarak gerçekleşmiştir. 2016 yılında STA ülkelerine yapılan ithalatın Türkiye'nin toplam ithalatı içindeki payı ortalama olarak yüzde 9 civarındadır. STA ülkelerinden Türkiye'nin en fazla ithalat yaptı̆ğ ülkeler sirasiyla Güney Kore, EFTA ülkeleri (EFTA ülkelerinden yapılan ithalatın yaklaşık yüzde 80'den fazlası İsviçre ile gerçekleştirilmektedir), İsrail, Mısır ve Malezya'dır.

Tablo 2: Türkiye'nin STA Ülkelerinden İthalatı (Bin \$)

\begin{tabular}{|c|c|c|c|c|c|c|}
\hline & 2012 & 2013 & 2014 & 2015 & 2016 & $\begin{array}{c}\text { Ortalama } \\
\text { Ithalat }\end{array}$ \\
\hline EFTA & 5.238 .265 & 10.652 .294 & 5.716 .743 & 3.137 .859 & 3.161 .772 & 5.581 .387 \\
\hline Arnavutluk & 98.989 & 82.390 & 96.281 & 49.578 & 20.602 & 69.568 \\
\hline Moldova & 135.053 & 260.974 & 246.928 & 216.926 & 147.737 & 201.524 \\
\hline Gürcistan & 180.351 & 201.738 & 232.596 & 223.107 & 211.680 & 209.894 \\
\hline Bosna Hersek & 111.649 & 124.330 & 171.424 & 250.089 & 288.291 & 189.157 \\
\hline Makedonya & 103.224 & 81.518 & 79.194 & 80.929 & 82.581 & 85.489 \\
\hline Karadağ & 17.936 & 11.515 & 7.373 & 8.001 & 23.364 & 13.638 \\
\hline Sirbistan & 205.538 & 251.957 & 273.901 & 238.299 & 288.237 & 251.586 \\
\hline Fas & 429.482 & 572.206 & 639.849 & 710.636 & 918.164 & 654.067 \\
\hline Tunus & 195.624 & 289.268 & 196.697 & 144.077 & 214.382 & 208.010 \\
\hline Misir & 1.342 .051 & 1.628 .868 & 1.434 .472 & 1.215 .905 & 1.443 .408 & 1.412 .941 \\
\hline Morityus & 6.167 & 7.784 & 7.939 & 6.672 & 5.000 & 6.712 \\
\hline Şili & 466.042 & 405.861 & 363.304 & 282.572 & 232.972 & 350.150 \\
\hline Suriye & 67.448 & 84.909 & 115.499 & 51.506 & 65.389 & 76.950 \\
\hline İsrail & 1.710 .401 & 2.417 .955 & 2.881 .262 & 1.672 .501 & 1.385 .605 & 2.013 .545 \\
\hline Filistin & 464 & 1.134 & 2.502 & 2.343 & 3.364 & 1.961 \\
\hline Ürdün & 95.996 & 70.573 & 126.068 & 127.919 & 102.259 & 104.563 \\
\hline Malezya & 1.278 .247 & 1.230 .783 & 1.160 .993 & 1.339 .168 & 1.996 .877 & 1.401 .214 \\
\hline Güney Kore & 5.660 .093 & 6.088 .318 & 7.548.319 & 7.057 .439 & 6.384 .156 & 6.547 .665 \\
\hline $\begin{array}{l}\text { STA } \\
\text { (Toplam) }\end{array}$ & 17.343.020 & 24.464.375 & 21.301.344 & 16.815 .526 & 16.975 .840 & 19.380.021 \\
\hline Pay $(\%)$ & $\mathbf{0 , 0 7}$ & $\mathbf{0 , 1 0}$ & 0,09 & 0,08 & 0,09 & 0,09 \\
\hline $\begin{array}{l}\text { Türkiye } \\
\text { (Toplam) }\end{array}$ & 236.545 .141 & 251.661 .250 & 242.177.117 & 207.234.359 & 198.617.392 & 227.247.052 \\
\hline
\end{tabular}

Kaynak: https://biruni.tuik.gov.tr/disticaretapp/menu.zul

Türkiye'nin STA Ülkeleri ile dış ticaret dengesi y1llar itibariyle Tablo 3'de verilmiştir. Tabloda da görüldügü gibi STA ülkeleriyle yapılan toplam ticarette Türkiye 2012, 2013 ve 2014 yıllarında dış ticaret açığı verirken, 2015 ve 2016 yıllarında dış ticaret fazlası vermiştir. Ülke bazında bakıldığında Güney Kore, EFTA ülkeleri, Malezya ve Şili dışındaki STA ülkeleriyle yapılan ikili ticarette Türkiye dış ticaret fazlası vermektedir. STA ülkeleriyle 2016 yılında yapılan ikili ticarette Türkiye'nin en büyük dış ticaret açığı verdiği ülke Güney Kore iken, en büyük dış ticaret fazlası verdiği ülke ise Mısır olmuştur. 
Tablo 3: Türkiye'nin STA Ülkeleri ile Dış Ticaret Dengesi (Bin \$)

\begin{tabular}{lrrrrrr}
\hline & \multicolumn{1}{c}{$\mathbf{2 0 1 2}$} & \multicolumn{1}{c}{$\mathbf{2 0 1 3}$} & \multicolumn{1}{c}{$\mathbf{2 0 1 4}$} & \multicolumn{1}{c}{$\mathbf{2 0 1 5}$} & \multicolumn{1}{c}{$\mathbf{2 0 1 6}$} & \multicolumn{1}{c}{$\begin{array}{c}\text { Ortalama } \\
\text { Denge }\end{array}$} \\
\hline EFTA & -2.637 .130 & -8.990 .385 & -1.921 .563 & 3.064 .344 & 105.025 & -2.075 .942 \\
Arnavutluk & 156.961 & 184.154 & 222.260 & 237.796 & 284.010 & 217.036 \\
Moldova & 89.411 & 14.998 & 39.813 & -15.319 & 114.645 & 48.710 \\
Gürcistan & 1.072 .958 & 1.044 .179 & 1.211 .194 & 885.633 & 965.111 & 1.035 .815 \\
Bosna Hersek & 139.875 & 149.756 & 150.598 & 42.481 & 20.671 & 100.676 \\
Makedonya & 171.273 & 212.458 & 268.770 & 243.684 & 295.457 & 238.328 \\
Karadağ & 11.196 & 17.625 & 27.667 & 30.296 & 28.443 & 23.045 \\
Sirbistan & 175.332 & 188.693 & 232.518 & 254.173 & 293.539 & 228.851 \\
Fas & 585.423 & 620.694 & 766.717 & 626.919 & 551.090 & 630.169 \\
Tunus & 601.114 & 602.889 & 718.344 & 674.984 & 696.062 & 658.679 \\
Misir & 2.337 .144 & 1.571 .494 & 1.863 .066 & 1.908 .971 & 1.290 .018 & 1.794 .139 \\
Morityus & 29.382 & 32.562 & 29.862 & 27.623 & 30.521 & 29.990 \\
Şili & -291.190 & -186.523 & -164.725 & -94.692 & -15.808 & -150.588 \\
Suriye & 430.512 & 939.564 & 1.685 .464 & 1.470 .526 & 1.256 .762 & 1.156 .566 \\
İsrail & 619.129 & 231.708 & 69.641 & 1.025 .638 & 1.570 .072 & 703.238 \\
Filistin & 62.695 & 74.373 & 88.442 & 79.881 & 91.008 & 79.280 \\
Ürdün & 674.986 & 673.620 & 780.953 & 706.837 & 608.544 & 688.988 \\
Malezya & -1.112 .773 & -958.709 & -845.969 & -982.085 & -1.675 .313 & -1.114 .970 \\
Güney Kore & $\mathbf{- 5 . 1 3 2 . 1 0 0}$ & -5.628 .267 & -7.077 .855 & -6.488 .803 & -5.865 .327 & -6.038 .470 \\
\hline STA & $\mathbf{- 2 . 0 1 5 . 8 0 2}$ & $\mathbf{- 9 . 2 0 5 . 1 1 7}$ & $\mathbf{- 1 . 8 5 4 . 8 0 3}$ & $\mathbf{3 . 6 9 8 . 8 8 7}$ & $\mathbf{6 4 4 . 5 3 0}$ & $\mathbf{- 1 . 7 4 6 . 4 6 1}$ \\
Türkiye & $\mathbf{- 8 4 . 0 8 3 . 4 0 4}$ & $\mathbf{- 9 9 . 8 5 8 . 6 1 3}$ & $\mathbf{- 8 4 . 5 6 6 . 9 5 9}$ & $\mathbf{- 6 3 . 3 9 5 . 4 8 7}$ & $\mathbf{- 5 6 . 0 7 2 . 9 3 6}$ & $\mathbf{- 7 7 . 5 9 5 . 4 8 0}$ \\
\hline
\end{tabular}

Kaynak: https://biruni.tuik.gov.tr/disticaretapp/menu.zul

\section{STA Ülkeleriyle Yapılan İkili Ticarette Türkiye'nin Karşılaştırmalı Üstünlüklerinin Analizi}

\subsection{Veri}

Çalışmada STA ülkeleri ile yapılan ikili ticarette Türkiye'nin karşılaştırmalı üstünlüklerini ölçmek amacıyla kullanılan veriler, Uluslararası Standart Ticaret Sınıflamasının (Standart International Trade Classification-SITC) revize edilmiş hali olan SITC Revize 3'e göre ele alınmıștır. Veriler Türkiye İstatistik Kurumu (TÜİK)'nun web sitesinden temin edilmiş olup, verilerden hareketle çeşitli endeks değerleri hesaplanarak yorumlanmıştır.

SITC, Birleşmiş Milletler tarafından hükümetlerin işbirliği ve uzmanların görüşleri alınarak hazırlanmış, uluslararası karşılaştırmalara olanak sağlamak amacıyla 1950 yılından itibaren kullanılması tavsiye edilmiştir. 1960'lara gelindiğinde birçok ülke dış ticaret istatistiklerini SITC ile ilişkili sınıflamalara göre düzenlemeye başlamış, uluslararası kuruluşların birçoğu da dış ticaret istatistikleri için SITC'yi temel almıştır. Dış ticaret hacminin büyümesi ve teknolojik yenilikler nedeniyle SITC'nin revize edilmesi ihtiyaç haline gelmiş, sınıflama 4 defa revize edilmiştir. SITC Revize 3 listesi birden beşe kadar basamaklı bir yapı ile oluşturulmuştur. 10 adet 1 basamaklı, 67 adet 2 basamaklı, 261 adet 3 basamaklı, 1.033 adet 4 basamaklı, 3.121 adet 5 basamaklı kod içeren 
bir yapısı vardır. Bununla birlikte, 2007 yılında yayımlanan SITC sinıflamasının 4. revizyonu da veri tabanlarında mevcut bulunmaktadır. SITC, özellikle uluslararası dış ticaret verilerinin karşılaştırılmasında kullanılmaktadır (TÜIKK, 2008: 22).

\subsection{Yöntem}

Uluslararası ticarette ülkelerin karşılaştırmalı olarak üstün oldukları ürünleri belirlemek amacıyla birçok endeks geliştirilmiş olmakla birlikte, yapılan çalışmalarda çoğunlukla Açıklanmış Karşılaştırmalı Üstünlükler Endeksi (Revealed Comparative Advantage Index-RCA) kullanılmaktadır. RCA endeksi, bir ülkenin karşılaştırmalı olarak üstünlüğe veya dezavantaja sahip olduğu malları belirlemek için kullanılan ölçütlerden birisidir.

RCA endeksi, bir ülke veya malın karşılaştırmalı üstünlüğünü daha iyi yansitmaktadır. Ancak söz konusu endeks bazı kısıtlamalara da sahiptir. Özellikle iki yanlı ticaretin söz konusu olmadiğı durumlarda (ya ithalat ya da ihracat sıfırsa), endeksin uygulanması sınırlı kalacaktır. Bu nedenle analiz yapılırken tüm ülkelerin iki yönlü dış ticaret ilişkisi içerisinde olduğu varsayılmıştır (Erkekoğlu, 2014: 18).

Açıklanmış karşılaştırmalı üstünlükler düşüncesi ilk olarak Liesner (1958) tarafından ortaya atılmıştır. Daha sonra Balassa (1965) tarafından işlevsel hale getirilmiştir. Ülkelerin mevcut ticaret verilerinden yararlanılarak karşılaştırmalı üstünlüğünü gösteren Balassa İndeksi, ülkeler arasındaki karşılaştırmalı üstünlüğün nedenine inmeden, görünen bir avantaj farkı olup olmadığını açıklamayı amaçlamaktadır (Seymen, 2009: 237). Bir ülkenin herhangi bir mal ihracatının toplam ihracata oranı şeklinde ifade edilen Liesner (1958) tarafından geliştirilen endeks $\left(\mathrm{RCA}=\mathrm{X}_{\mathrm{ij}} / \mathrm{X}_{\mathrm{nj}}\right)$ oldukça basit düzeyde kalmıştır. Daha sonra bu endeks Balassa (1965) tarafından geliştirilerek $R C A=\left(X_{i j} / X_{i t}\right) /\left(X_{n j} / X_{n t}\right)$ şeklini almıştır. Bu çalışmada aşağıda yer alan endeks kullanılmış olup, söz konusu endeks Balassa tarafından ortaya koyulan RCA endeksinin geliştirilmiş şeklidir.

$$
\mathrm{RCA}_{\mathrm{ij}}=\ln \left[\left(\mathrm{X}_{\mathrm{ij}} / \mathrm{X}_{\mathrm{it}}\right) /\left(\mathrm{M}_{\mathrm{ij}} / \mathrm{M}_{\mathrm{it}}\right)\right] \mathrm{x} 100
$$

Denklemde, $R A_{i j} i$ ülkesinin $\mathrm{j}$ mal grubundaki açıklanmış karşılaştırmalı üstünlükler katsayısını, $X_{\mathrm{ij}} \mathrm{i}$ ülkesinin $\mathrm{j}$ mal grubundaki ihracatını, $X_{\mathrm{it}} \mathrm{i}$ ülkesinin toplam ihracatını, $M_{i j} \mathrm{i}$ ülkesinin $\mathrm{j}$ mal grubundaki ithalatını, $\mathrm{M}_{\mathrm{it}} \mathrm{i}$ ülkesinin toplam ithalatını göstermektedir.

RCA değerinin 0.50 'den büyük olması ilgili mal grubunda karşılaştırmalı üstünlüğün, -0.50'den küçük olması karşılaştırmalı olarak dezavantajın olduğunu göstermektedir. Endeks değerinin 0.50 ile -0.50 arasında olması halinde ise, karşılaştırmalı üstünlük veya dezavantaj olup olmadığına ilişkin bir karar verilememektedir. 


\subsection{Analiz}

Çalışmanın bu kısmında Türkiye ile STA ülkeleri arasındaki ikili dış ticaret verileri RCA endeksi yardımıyla analiz edilerek, Türkiye'nin STA ülkeleri ile yapılan ticarette karşılaştırmalı olarak üstün olduğu ürünler ve karşılaştırmalı olarak dezavantaja sahip olduğu ürünler belirlenmiştir.

Tablo 4'te Türkiye'nin serbest ticaret anlaşması yaptı̆̆ 1 ülkelerle olan diş ticareti SITC-3 sınıflandırmasına göre toplam olarak sunulmuştur. Tabloda da görüldüğ̈ üzere 2016 yılında Türkiye ile STA ülkeleri arasındaki ticarette önemli yer tutan kalemler canlı hayvanlar ve gida maddeleri (0), başka yerde belirtilmeyen kimya sanayi ve buna bağlı sanayi ürünleri (5), başlıca sınıflara ayrılan işlenmiş mallar (6), makine ve ulaştırma araçları (7) ve çeşitli mamul eşya (8)'dır. STA ülkeleriyle yapılan ticarette toplam diş ticaret dengesine (DTD) bakıldığında Türkiye'nin dış ticaret fazlası verdiği görülmektedir. Bununla birlikte 9 mal gurubundan oluşan SITC-3 sınıflandırmasına göre beş mal grubunda ise $(2,3,4,5$ ve 7 nolu mal grupları) Türkiye toplam olarak STA ülkelerine karşı dış ticaret açığı vermektedir.

Tablo 4: SITC-3’e Göre Türkiye'nin STA Ülkeleriyle Ticareti (2016, Bin\$)

\begin{tabular}{lrrr}
\hline & İhracat & \multicolumn{1}{c}{ İthalat } & \multicolumn{1}{c}{ DTD } \\
\hline 0-Canlı hayvanlar ve gıda maddeleri & 1.430 .524 & 587.849 & 842.675 \\
1-İçkiler ve tütün & 193.415 & 15.423 & 177.992 \\
2-Akaryakıt hariç yenilmeyen hammaddeler & 240.029 & 634.627 & -394.598 \\
3- Mineral yakıtlar, yağlar ve alkali ürünler & 775.149 & 880.595 & -105.446 \\
4-Hayvansal, bitkisel katı ve sıvı yağlar, mumlar & 166.817 & 681.289 & -514.472 \\
5-Başka yerde belirtilmeyen kimya sanayi ve buna bağlı san. ürn. & 1.427 .070 & 3.994 .234 & -2.567 .164 \\
6-Başlıca sınıflara ayrılan işlenmiş mallar & 5.290 .526 & 3.263 .946 & 2.026 .580 \\
7-Makine ve ulaştırma araçları & 3.622 .031 & 4.528 .812 & -906.781 \\
8-Çeşitli mamul eşya & 2.334 .494 & 1.208 .862 & 1.125 .632 \\
9-STIC'de sınıflandırılmamış eşya & 2.130 .094 & 1.171 .457 & 958.637 \\
\hline
\end{tabular}

Kaynak: TÜiK verilerinden yararlanılarak yazar tarafindan oluşturulmuştur.

Tablo 5'te Türkiye'nin açıklanmış karşılaştırmalı üstünlüğe veya dezavantaja sahip olduğu malların RCA endeksi değerleri, 2012-2016 döneminde 5 yllık ortalama esas alınarak verilmiştir. Tablodan da görüldügü gibi STA ülkeleriyle yapılan karşılıklı ticarette, Türkiye canlı hayvanlar ve gıda maddelerinde (0), içkiler ve tütün (1), başlıca sınıflara ayrılan işlenmiş mallar (6) ve çeşitli mamul eşya (8) ticaretinde karşılaştırmalı üstünlüğe sahipken, akaryakıt hariç yenilmeyen hammaddeler (2), hayvansal, bitkisel katı ve sıv1 yağlar, mumlar (4) ve başka yerde belirtilmeyen kimya sanayi ve buna bağlı sanayi ürünleri (5) ticaretinde de karşılaştırmalı dezavantaja sahiptir. Geri kalan 3 ürün grubunda ise karşılaştırmalı üstünlük veya dezavantaj olup olmadığına ilişkin bir karar verilememiştir. 
Tablo 5: STA Ülkeleri ile Yapılan Ticarette Türkiye'nin RCA Endeksi Değerleri (2012-2016 Dönemi Beş Yıllık Ortalama)

\begin{tabular}{|l|c|c|c|c|c|c|c|c|c|c|}
\hline & $\mathbf{0}$ & $\mathbf{1}$ & $\mathbf{2}$ & $\mathbf{3}$ & $\mathbf{4}$ & $\mathbf{5}$ & $\mathbf{6}$ & $\mathbf{7}$ & $\mathbf{8}$ & $\mathbf{9}$ \\
\hline EFTA & 0,48 & 0,09 & 0,51 & $-1,21$ & $-1,70$ & $-1,82$ & 0,25 & 0,28 & 0,19 & 0,15 \\
Arnavutluk & 2,51 & 5,94 & $-3,09$ & $-2,33$ & $-1,07$ & 2,04 & $-0,60$ & 1,42 & 1,27 & 4,61 \\
Moldova & $-0,03$ & 0,24 & $-4,43$ & 12,52 & 2,67 & 4,60 & 2,32 & 1,15 & 0,56 & 5,61 \\
Gürcistan & $-0,34$ & 7,64 & $-2,11$ & $-2,28$ & $-4,28$ & 0,28 & 0,44 & 2,14 & $-0,37$ & $-3,30$ \\
Bosna Hersek & $-1,02$ & $-0,04$ & $-10,65$ & $-2,59$ & $-12,72$ & 0,89 & 0,52 & 1,57 & 1,73 & $-1,85$ \\
Makedonya & 9,22 & 1,48 & $-0,87$ & - & $-0,03$ & 2,44 & $-0,62$ & 0,29 & 1,38 & $-0,54$ \\
Karadağ & 8,26 & $-1,49$ & $-11,16$ & - & - & 9,35 & $-0,46$ & 10,71 & 9,17 & 1,06 \\
Sirbistan & 0,06 & 0,93 & $-2,20$ & $-3,55$ & $-1,48$ & 0,11 & $-0,07$ & 0,43 & 1,32 & $-12,30$ \\
Fas & $-1,93$ & 11,54 & $-2,36$ & $-0,43$ & 1,61 & $-1,16$ & 1,90 & $-0,10$ & 0,37 & $-3,13$ \\
Tunus & 0,00 & 9,36 & 0,16 & $-0,29$ & $-11,05$ & $-2,24$ & 1,82 & 0,24 & 0,13 & $-9,57$ \\
Misır & 0,62 & 12,69 & $-0,85$ & 1,60 & $-1,42$ & $-1,67$ & 0,16 & 2,32 & $-0,40$ & $-2,53$ \\
Morityus & 7,48 & 1,06 & $-1,86$ & - & - & 8,65 & $-0,29$ & 10,36 & $-1,86$ & - \\
Şili & $-1,66$ & 1,23 & $-1,93$ & 8,44 & $-12,12$ & 0,31 & $-0,58$ & 5,43 & 12,79 & $-10,99$ \\
Suriye & 0,54 & 12,13 & $-3,98$ & 9,59 & 10,97 & $-0,11$ & 0,96 & 1,58 & 1,33 & $-0,15$ \\
İsrail & 2,31 & 11,50 & $-1,31$ & $-4,33$ & 12,18 & $-1,32$ & 1,86 & 1,23 & 1,49 & $-1,96$ \\
Filistin & $-0,39$ & 9,84 & $-4,64$ & - & - & 8,19 & 9,43 & 5,36 & 6,96 & - \\
Ürdün & 3,67 & 11,07 & $-2,23$ & 13,86 & 8,00 & $-2,52$ & 1,40 & 3,22 & 3,94 & $-9,44$ \\
Malezya & 1,32 & 3,71 & $-0,62$ & 2,54 & $-3,61$ & 0,08 & $-0,18$ & $-0,47$ & 1,14 & 3,27 \\
Güney Kore & 4,76 & 3,06 & 1,72 & 3,22 & 11,70 & 0,22 & $-0,52$ & $-1,04$ & $-0,20$ & 0,41 \\
\hline STA & 1,13 & 2,43 & $-1,02$ & $-0,01$ & $-0,94$ & $-0,95$ & 0,62 & $-0,25$ & 0,62 & $-0,19$ \\
\hline
\end{tabular}

Kaynak: TÜİK verilerinden yararlanılarak yazar tarafindan oluşturulmuştur.

Canlı hayvanlar ve gıda maddeleri (0) ticaretinde, Türkiye STA ülkelerinin çoğunluğuna karşı karşılaştırmalı üstünlüğe sahip olup, en fazla karşılaştırmalı üstünlüğe sahip olunan ülkeler sırasıyla Makedonya, Karadağ, Morityus ve Güney Kore'dir. Bu mal grubunda en fazla karşılaştırmalı dezavantaja sahip olunan ülkeler ise sırasıyla Fas, Şili ve Bosna Hersek'tir.

İçkiler ve tütün (1) ticaretinde, Karadağ ve Bosna Hersek dışında Türkiye STA ülkelerinin tamamına karşı karşılaştırmalı üstünlüğe sahiptir.

Akaryakıt hariç yenilmeyen hammaddeler (2) ticaretinde, Güney Kore, EFTA ve Tunus dışında Türkiye STA ülkelerinin tamamına karşı karşılaştırmalı dezavantaja sahiptir. Türkiye'nin ikili ticarette en fazla karşılaştırmalı dezavantaja sahip olduğu ülkeler sırasıyla Karadağ, Bosna Hersek ve Filistin'dir.

Mineral yakıtlar, yağlar ve alkali ürünler (3) ticaretinde, Türkiye STA ülkelerinin bir kısmına karşı karşılaştırmalı üstünlüğe sahip iken bazılarına karşı ise karşılaştırmalı dezavantaja sahiptir. Türkiye'nin en fazla karşılaştırmalı üstünlüğe sahip olduğu ülkeler sırasıyla Ürdün, Moldova ve Suriye iken, en fazla dezavantaja sahip olduğu ülkeler ise sırasıyla İsrail, Sırbistan ve Bosna Hersek’tir. 
Hayvansal, bitkisel katı ve sıvı yağlar, mumlar (4) ticaretinde, Türkiye STA ülkelerinin bir kısmına karşı karşılaştırmalı üstünlüğe sahip iken, önemli bir kısmına karşı ise karşılaştırmalı dezavantaja sahiptir. Türkiye'nin en fazla karşılaştırmalı üstünlüğe sahip olduğu ülkeler sırasıyla İsrail, Güney Kore ve Suriye iken, en fazla dezavantaja sahip olduğu ülkeler sırasıyla Bosna Hersek, Şili ve Tunus'tur.

Başka yerde belirtilmeyen kimya sanayi ve buna bağlı sanayi ürünleri (5) ticaretinde, Türkiye'nin en fazla karşılaştırmalı üstünlüğe sahip olduğu ülkeler sirasıyla Karadağ, Morityus ve Filistin iken, en fazla dezavantaja sahip olduğu ülkeler sirasıyla Ürdün, Tunus ve EFTA'dır.

Başlıca sınıflara ayrılan işlenmiş mallar (6) ticaretinde, Türkiye STA ülkelerinin çoğunluğuna karşı karşılaştırmalı üstünlüğe sahip olup, en fazla karşılaştırmalı üstünlüğe sahip olunan ülkeler sirasıyla Filistin, Moldova ve Fas'tır. Bu mal grubunda en fazla karşılaştırmalı dezavantaja sahip olunan ülkelere ise sırasıyla Makedonya, Arnavutluk ve Şili'dir.

Makine ve ulaştırma araçları (7) ticaretinde, Türkiye STA ülkelerinin çoğunluğuna karşı karşılaştırmalı üstünlüğe sahip olup, en fazla karşılaştırmalı üstünlüğe sahip olunan ülkeler sırasıyla Karadağ, Morityus ve Şili'dir. Bu ürün grubu ticaretinde karşılaştırmalı dezavantaja sahip olunan tek ülke ise Güney Kore'dir.

Çeşitli Mamul Eşya (8) ticaretinde, Türkiye STA ülkelerinin çoğunluğuna karşı karşılaştırmalı üstünlüğe sahip olup, en fazla karşılaştırmalı üstünlüğe sahip olunan ülkeler sırasıyla Şili, Karadağ ve Filistin'dir. Bu ürün grubu ticaretinde karşılaştırmalı dezavantaja sahip olunan tek ülke ise Morityus'dir.

STIC'de sınıflandırılmamış eşya (9) ticaretinde, Türkiye STA ülkelerinin çoğunluğuna karşı karşılaştırmalı dezavantaja sahip olup, en fazla dezavantaja sahip olduğu ülkeler sırasıyla Sırbistan, Şili ve Tunus'tur. En fazla karşılaştırmalı üstünlüğe sahip olunan ülkeler ise sırasıyla Moldova, Arnavutluk ve Malezya'dır.

Tablo 6'da, 2016 yılı için Türkiye'nin açıklanmış karşılaştırmalı üstünlüğe veya dezavantaja sahip olduğu malların RCA endeksi değerleri verilmiştir. Tablodan da takip edileceği üzere STA ülkeleriyle yapılan karşılıklı ticarette Türkiye canlı hayvanlar ve gıda maddelerinde (0), içkiler ve tütün (1), çeşitli mamul eşya (8) ve STIC'de sınıflandırılmamış eşya (9) ticaretinde karşılaştırmalı üstünlüğe sahipken, akaryakıt hariç yenilmeyen hammaddeler (2), hayvansal, bitkisel katı ve sıvı yağlar, mumlar (4) ve başka yerde belirtilmeyen kimya sanayi ve buna bağlı sanayi ürünleri (5) ticaretinde de karşılaştırmalı dezavantaja sahiptir. Geri kalan mineral yakıtlar, yağlar ve alkali ürünler (3), başlıca sınıflara ayrılan işlenmiş mallar (6) ve makine ve ulaştırma araçları (7) ticaretinde ise karşılaştırmalı üstünlük veya dezavantaj olup olmadığına ilişkin bir karar verilememiştir. 
Tablo 6: STA Ülkeleri ile Yapılan Ticarette Türkiye'nin RCA Endeksi Değerleri (2016)

\begin{tabular}{|l|c|c|c|c|c|c|c|c|c|c|}
\hline & $\mathbf{0}$ & $\mathbf{1}$ & $\mathbf{2}$ & $\mathbf{3}$ & $\mathbf{4}$ & $\mathbf{5}$ & $\mathbf{6}$ & $\mathbf{7}$ & $\mathbf{8}$ & $\mathbf{9}$ \\
\hline EFTA & 0,12 & $-0,68$ & $-0,18$ & $-1,13$ & $-1,47$ & $-2,21$ & 0,04 & 0,04 & $-0,43$ & 0,68 \\
Arnavutluk & 0,41 & 5,82 & $-3,68$ & - & - & 0,64 & 0,79 & 0,08 & $-0,21$ & $-7,28$ \\
Moldova & 0,03 & $-0,15$ & $-5,25$ & - & - & 2,30 & 3,14 & 10,45 & 0,18 & $-0,64$ \\
Gürcistan & $-0,55$ & 7,93 & $-1,12$ & $-1,66$ & $-4,25$ & 1,08 & 0,45 & 0,92 & $-0,49$ & $-2,66$ \\
Bosna Hersek & $-1,51$ & 0,57 & $-9,41$ & $-8,37$ & $-13,47$ & 1,02 & 0,67 & 1,83 & 2,30 & 1,52 \\
Makedonya & 8,83 & 3,65 & $-1,26$ & - & $-0,77$ & 9,35 & $-0,53$ & 0,27 & 0,51 & 0,64 \\
Karadağ & 7,96 & - & $-2,53$ & - & - & 13,14 & $-1,23$ & 10,77 & 13,91 & - \\
Sirbistan & 1,04 & 0,95 & $-2,81$ & - & $-2,85$ & 0,17 & $-0,36$ & 0,63 & 1,03 & $-13,65$ \\
Fas & $-2,37$ & 11,50 & $-2,50$ & - & 8,27 & $-0,84$ & 1,98 & $-0,28$ & 0,87 & $-3,15$ \\
Tunus & $-0,17$ & - & 0,06 & - & $-10,31$ & $-2,46$ & 2,01 & $-0,05$ & 0,26 & 1,00 \\
Misır & 0,56 & 14,34 & $-0,79$ & 1,98 & $-1,94$ & $-1,57$ & 0,40 & 1,76 & $-0,28$ & $-12,00$ \\
Morityus & 7,61 & - & $-1,62$ & - & & 12,78 & $-0,65$ & 10,85 & $-1,65$ & - \\
Şili & $-2,70$ & 1,04 & $-9,87$ & - & $-14,52$ & $-0,12$ & $-0,19$ & 12,73 & 12,11 & - \\
Suriye & 0,04 & - & $-3,98$ & - & 11,09 & $-0,77$ & 0,88 & 11,22 & 8,90 & - \\
İsrail & 1,81 & 14,75 & $-1,30$ & $-4,47$ & 11,00 & $-1,41$ & 1,51 & 0,83 & 1,39 & $-1,99$ \\
Filistin & $-0,72$ & - & $-1,85$ & - & - & 8,84 & 9,74 & 6,11 & 7,30 & - \\
Ürdün & 9,56 & 11,74 & $-1,14$ & 12,08 & - & $-2,56$ & 1,84 & 2,54 & 2,89 & 1,55 \\
Malezya & 1,80 & 1,95 & $-0,33$ & 4,48 & $-3,86$ & $-0,05$ & $-0,75$ & $-0,71$ & 1,41 & 3,75 \\
Güney Kore & 5,23 & 4,09 & 2,04 & 2,22 & 10,75 & 0,35 & $-0,83$ & $-0,54$ & $-0,09$ & 0,59 \\
\hline STA & 0,85 & 2,49 & $-1,01$ & $-0,16$ & $-1,44$ & $-1,07$ & 0,45 & $-0,26$ & 0,62 & 0,56 \\
\hline
\end{tabular}

Kaynak: TÜİK verilerinden yararlanılarak yazar tarafından oluşturulmuştur.

STA ülkeleri ile yapılan dış ticaret verileri toplam olarak ele alındığında gerek 2016 yılına gerekse 2012-2016 döneminde Türkiye'nin 0, 1 ve 8 numaralı mal guruplarında karşılaştırmalı üstünlüğe, 2, 4 ve 5 numaralı mal guruplarında ise karşılaştırmalı dezavantaja sahip olduğu görülmektedir.

\section{Sonuç}

Küresel ticaretteki serbestleşme düzeyini yeterli görmeyen ülkeler veya ticaret blokları diğer ülkelerle tercihli ticaret anlaşmaları yaparak karşılıklı ekonomik ve ticari ilişkileri geliştirme arayışına girmektedirler. Böylece serbest ticaret sayesinde ihtiyaç duydukları hammadde, aramalı ve nihai ürünleri birbirlerinden temin etme imkanına kavuşan ülkelerde hem ticaret hacmi hem de ekonomik büyüme hızı artmaktadır.

Serbest ticaretin nimetlerinden yararlanmak için AB bir çok ülke ile STA imzalamıştır. Gümrük birliğinin gereği olarak Türkiye bu ülkelerin bir kısmıyla STA imzalamış olup, bir kısmıyla ise müzakerelere devam etmektedir. Bu kapsamda, 22 ülkeyi kapsayan 19 STA yürürlükte bulunmaktadır. Türkiye 
yaklaşık olarak ihracatının yüzde 12'sini, ithalatının ise yüzde 9'unu STA ülkeleriyle yapmaktadır. Türkiye STA ülkeleri içerisinde en fazla ihracatı EFTA'ya yaparken, en fazla ithalatı Güney Kore'den yapmaktadır. Dış ticaret dengesi açısından bakıldığında Güney Kore, EFTA ülkeleri, Malezya ve Şili dışında kalan STA ülkeleriyle yapılan ikili ticarette Türkiye'nin dış ticaret fazlası verdiği görülmektedir.

Türkiye ile STA ülkeleri arasında 2012-2016 döneminde gerçekleşen diş ticaret verileri dikkate alındığında, Türkiye'nin canlı hayvanlar ve gida maddeleri (0), içkiler ve tütün (1) ve çeşitli mamul eşya (8) mal guruplarında karşılaştırmalı üstünlüğe; akaryakıt hariç yenilmeyen hammaddeler (2), hayvansal, bitkisel katı ve sıvı yağlar, mumlar (4) ve başka yerde belirtilmeyen kimya sanayi ve buna bağlı sanayi ürünleri (5) mal guruplarında ise karşılaştırmalı dezavantaja sahip olduğu görülmektedir. Mineral yakıtlar, yağlar ve alkali ürünler (3), başlıca sınıflara ayrılan işlenmiş mallar (6) ve makine ve ulaştırma araçları (7) ticaretinde ise Türkiye'nin karşılaştırmalı üstünlük veya dezavantaja sahip olup olmadığına ilişkin bir karar verilememiştir.

Bugüne kadar anlaşma yapılan STA ülkelerinin büyük bir bölümüne karşı Türkiye dış ticaret fazlası vermektedir. Bu nedenle gümrük birliği kapsamında yapılacak STA'lar ile ilgili temel sorun AB ile STA imzalayan bazı ülkelerin Türkiye ile anlaşmaya yanaşmamaları ve AB'nin STA imzalamak için müzakere sürecine girdiği, başta ABD olmak üzere, dünya ekonomisinde ağırlığı olan ülkelerinde Türkiye ile anlaşmaktan kaçınma ihtimalleridir. İkili ticarette Türkiye'yi dezavantajlı konumu getiren/getirecek bu durum ciddi diş ticaret açıklarına neden olacaktır. Dolayısıyla bugünlerde oldukça gündemde olan gümrük birliğinin güncellenmesi tartışmaları kapsamında bu sorununda çözülmesi hayati önem taşımaktadır.

\section{Kaynakça}

AB Bakanlığı (2017), Türkiye-AB Arasında Gümrük Birliğini Tesis Eden 1/95 Sayılı Ortaklık Konseyi Karar1, www.ab.gov.tr/files/_files/Gumruk_Isbirligi/1-95.doc, (Erişim Tarihi: 20.07.2017).

Akman, Sait (2013), AB - ABD Transatlantik Ticaret ve Yatırım Ortaklığı (TTIP) ve Türkiye, Rapor No: R201305, Türkiye Ekonomi Politikaları Araştırma Vakfı (TEPAV), Ankara.

Balassa, B. (1965), "Trade Liberalisation and Revealed Comparative Advantage", The Manchester School of Economic and Social Studies, 33, 99-123.

Ekonomi Bakanlığı (2017a), Serbest Ticaret Anlaşmalarına İlişkin Genel Bilgi, http://www.ekonomi.gov.tr/portal/faces/home/disIliskiler/SerbestTic/Genel_Bi lgi.html?\#!\%40\%40\%3F_adf.ctrl-state\%3D4y7ffahf5_208, (Erişim Tarihi: 13.07.2017). 
Ekonomi Bakanlığı(2017b), Serbest Ticaret Anlaşmalarına İlişkin Genel Bilgi, http://www.ekonomi.gov.tr/portal/content/conn/UCM/path/Contribution\%20F olders/web/D\%C4\%B1\%C5\%9F\%20\%C4\%B0li\%C5\%9Fkiler/Serbest\%20Ti caret $\% 20$ Anla\%C5\%9Fmalar\%C4\%B1/ekler/\%C3\%9Clkemizin\%20STA\%20 politikas\%C4\%B1na\%20ili\%C5\%9Fkin\%20detayl\%C4\%B1\%20bilgi.pdf?lve (Erişim Tarihi: 13.07.2017).

Erdem, C. (2015), Serbest Ticaret Anlaşmalarının Türkiye'nin Tarımsal Dış Ticaretine Etkileri, Gıda Tarım ve Hayvancılık Bakanlığı Avrupa Birliği ve Dış İlişkiler Genel Müdürlüğü, AB Uzmanlık Tezi.

Eren, M. (2013), “Türkiye'nin Serbest Ticaret Anlaşmalarının Dış Ticaretine Etkileri ve Sorunlar", Maliye Finans Yazıları, 27(98), 28-47.

Erkekoğlu, Hatice ve Diğerler (2014), "Kayseri İlinin Mobilya Sektörü Rekabet Gücü: Açıklanmış Karşılaştırmalı Üstünlük Endeksi”, Erciyes Üniversitesi İktisadi ve İdari Bilimler Fakültesi Dergisi, 44, 1-22.

Goode, W. (2005), Negotiating Free-Trade Agreements: A Guide, Canberra, Aiustralian Department of Foreign Affairs and Trade.

IMC, Paper On- Free Trade Agreement, IMC- Economic Research \& Training Foundation, http://www.imcnet.org/cms/public/content/ertf_thoughtpaper/2.\%20Free\%20T rade\%20Agreement.pdf (Erişim Tarihi: 20.07.2017).

Liesner, H.H. (1958), "The European Common Market and British Industry", Economic Journal, 68(270), 302-316.

Kinnman, S. ve Hagberg, T. (2012), Potential Effects from an EU-US Free Trade Agreement-Sweden in Focus, Kommerskollegium National Board of Trade, Sweden.

Koçtürk, O.M. ve Kocaefe, A. (2014), "Serbest Ticaret Anlaşmalarının Türk Dış Ticareti Üzerine Etkileri”, Tarım Ekonomisi Dergisi, 20(2), 65-77.

Sandalcılar, A. ve Palyoş, E. (2017), "Transatlantik Ticaret ve Yatırım Ortaklığı (TTIP) Üzerine Bir Değerlendirme", Uluslararası Ekonomi, İşletme ve Politika Dergisi, 1(1), 35-46.

Seymen, Dilek Aykut, (2009), Türkiye'nin Dış Ticaret Yapısı ve Rekabet Gücü, Dokuz Eylül Üniversitesi Yayını, İzmir.

TÜIK, D1ş Ticaret İstatistikleri, https://biruni.tuik.gov.tr/disticaretapp/menu.zul, (Erişim Tarihi: 20.05.2017).

TÜİK (2008), Dış Ticaret İstatistikleri ve Endeksleri: Sorularla Resmi İstatistikler Dizisi-2, Ankara. 